\title{
Problem-Based Learning Tools Assisted by Google Classroom on Momentum and Impulse for High School Student
}

\author{
Melta Zahra ${ }^{1, *}$ Jumadi $^{2}$ \\ ${ }^{1}$ Master of Physics Education, Faculty Of Mathematic and Natural Sciences, Universitas Negeri Yogyakarta, \\ Indonesia \\ ${ }^{2}$ Department of Physics Education, Faculty of Mathematics and Natural Sciences, Universitas Negeri \\ Yogyakarta, Indonesia. \\ *Corresponding author. Email: Meltazahra.2019@student.uny.ac.id
}

\begin{abstract}
This research aimed to develop physics learning tools (syllabus, lesson plan, student worksheet, material) based on Problem Based Learning assisted by Google classroom on Momentum and impulse that are suitable for use in learning. This research was a research using 4D design. The stages consisted of the defining, planning, developing and dessimination stages. Researchers analyzed the curriculum, learning materials, and the needs of students. At the design stage, the researchers made a design of the learning tools. The product was validated by two experts. At the dessimination stage, learning tools were tested on students at MAN 1 Yogyakarta. The results showed that the learning device was very good to use in learning.
\end{abstract}

Keywords: PBL, Learning tools, Google classroom

\section{INTRODUCTION}

Natural science explores and studies natural phenomena through a series of scientific processes. In this modern era, science learning needs to keep up with the times [1]. The development of science and technology requires educators (including teachers) to be able to compete globally. Advances in technology make it easier for students to obtain information from various media [2]. However, this must be done wisely because when accessing information, students will find the positive and negative sides of technology [3].

Since December 2019 the world has been shocked by the COVID-19. Including Indonesia, in early March 2020, Indonesia was hit by this plague virus. COVID-19 can spread very quickly. To reduce the risk of spreading the plague virus, the government has initiated social distancing, including in education, so the learning process must be online[4]. This requires teachers and students to be able to adjust and be able to use technology [5]. So that teachers and students must have facilities for distance learning.

Physics is a branch of science that is concerned with finding concepts in everyday life. Physics is very influential in the development of science and technology. There are many physics concepts applied to technology, such as communication technology, transportation, and astronomy [6]. Current learning emphasizes the concept of learning that is centered on students by providing direct experience [7]. The teacher can see the achievement of students in learning from the ability of students to understand the concepts [8]. Although the concepts of physics are very important to learn, there are still many students who do not like learning physic. Most students find physics concepts difficult to understand [9]. One of the reasons for not implementing the learning process according to the theme [10].

The results of observations in class X MAN 1 Yogyakarta show that in learning activities, teachers have not actively involved students. Teacher centered learning activities. Learning is mostly done by the lecture method. Most of the lessons only focus on theory and on memorizing mathematical equations. This causes students to be not interested in learning physics, learning becomes less fun for them. Most of the students consider physics lessons difficult to understand because it contains too many abstract 
formulas and concepts. During learning, only a few students dared to express opinions or responses related to physics concepts. Therefore, a learning model that requires students to take an active role in learningis needed, one of which is the problem-based learning (PBL) model

Problem based learning is learning that presents a real problem for gaining knowledge. The problems presented are in the form of phenomena that are often found in everyday life, so that students can more easily understand [11]. The steps of the PBL model are asking questions, collecting data, concluding, communicating, and evaluating. The purpose of learning with the PBL model is to form the mindset of students so that they can solve physics problems by not only depending on mastery of concepts, but also building relationships between all information and concepts the problem [12].

Developments in technology make learning activities more effective by using multimedia and internet access. Online learning provides many benefits for students because it can be accessed easily and has unlimited information [13]. One of the commonly used online lessons is google classroom [14]. Learning using Google Classroom which provides interesting features and can be used on computers and cellular phones [15]. students can visit the site https://classroom.google.com or download the application via the playstore on android or the app store on iOS with the keyword google classroom [16].

not only teachers but students can also access it easily.

From the explanation above, the researcher thought that learning that can adapt to the demands of education in this pandemic era is needed. This pandemic is a big challenge for education. A teacher must continue to provide effective learning, one of which is by utilizing online learning media. Learning can be done using google classrroom which can be accessed easily and for free [17]. Based on the results of previous research, students are greatly helped by the existence of google classroom which can facilitate the learning process [18].

\section{RESEARCH METHOD}

This research was conducted at MAN 1 Yogyakarta in April 2020. This research was a development research. The product developed was in the form of problem based learning tools assisted by google classroom. The research design used was the 4D model proposed by Thiagarajan, Semmel, \& Semmel (1974) which consisted of define, design, develop, and dissemination stage.

At the define stage, an analysis of the needs of students, curriculum, material, and student specifications was carried out. The analysis was carried out by interview and observation. The research instrument used was in the form of a product feasibility questionnaire given to media experts and material experts, as well as physics learning practitioners. In addition, to find out the responses of students, a product questionnaire instrument was used. At the design stage, the initial product design was done. The products developed are syllabus, lesson plan, and student worksheet. The next stage was the develop stage, at this stage, validation was carried out to determine the feasibility of the product. And the last stage was the dissemination stage, at this stage the final product was disseminated through reports

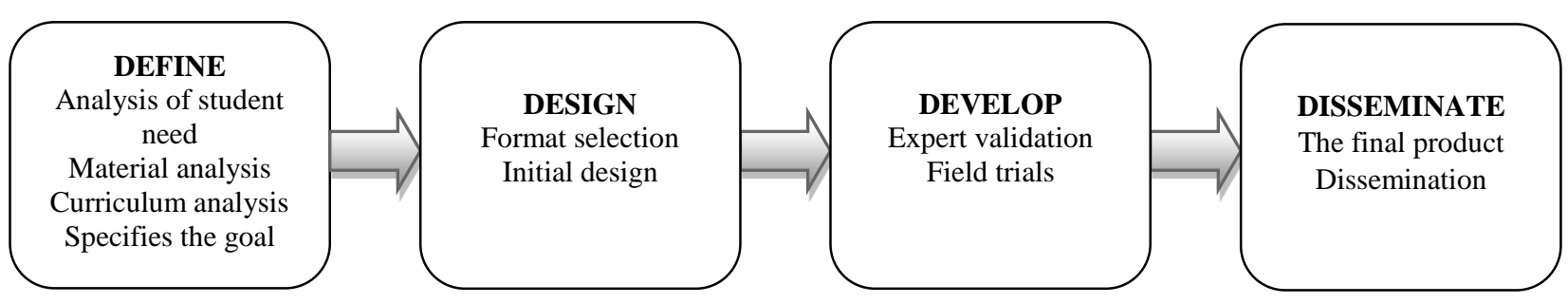

Figure 1 The stages of research and development of problem-based learning tools

The data analysis technique in this study used expert validation data analysis. The validators provided an assessment of each aspect of the instrument. If each aspect was considered feasible, the instrument can be used in research. If there are aspects that are deemed inappropriate, the instrument must be revised according to the validators' suggestions and comment. The validation scores by the validators were analyzed in the form of this equation:
$S S=\frac{\overline{S S}}{S_{m}}$

With SS is the score, $\overline{S S}$ is the average score and $S_{m}$ is the maximun score. To interpret the percentage of validation results, the assessment criteria in table 1 are used: 
Table 1. Interpretation of the validation result assessment score

\begin{tabular}{|c|c|c|}
\hline Interval & Criteria & Conclusion \\
\hline $3,26-4,00$ & Strongly Valid & Can be used without revision \\
\hline $2,51-3,25$ & Valid & Can be used with minor revision \\
\hline $1,76-2,50$ & Invalid & Can be used because it needs major revision \\
\hline $1,00-1,75$ & Strongly Valid & Cannot be used \\
\hline
\end{tabular}

The conclusion of these criteria is that if the validation result score is less than 2.51 , the product must be corrected according to the suggestions from the validators. And if the result is more than 2.51 then the product is suitable for use

\section{RESULT AND DISCUSSION}

This development research aimed to produce problem-based learning tools through Google classroom. Based on the research and development steps that have been carried out, this development research consists of several stages: define, design, develop and disseminate.

\subsection{Define Stage}

At the define stage, the researcher did student needs analysis, curriculum analysis, material analysis, and teacher analysis. From the results of observations made in MAN 1 Yogyakarta, it was found that in the learning process the teacher had not developed Problem-based learning tools. In the learning process, there were still many students who found it difficult to understand the lesson. One of the factors was because students found it difficult to adjust to the learning model applied by the teacher. So a learning model that can train students to get used to solving problemsis needed. The diversity of student learning styles in understanding lessons requires attention in the teaching and learning process. Therefore, it is necessary to develop physics learning tools consisting of a syllabus, lesson plans, student worksheets and teaching materials according to student needs. Before developing physics learning tools, researchers conducted an analysis to students.

From the results of the initial analysis, it was found that there were still many students who were not proficient in solving a physics problem, especially in class X MIPA, so that the learning tools developed in this study contained a syllabus, lesson plan, student worksheet, and PBL-based teaching material for class $X$ MIPA. Then the researcher analyzed the core competencies and basic competencies, then described the learning indicators. Based on the curriculum analysis, momentum and impulse were selected. Because learning that was originally face-to-face turned into online learning, researchers used google classroom. So that learning tools are made by adjusting online learning.

\subsection{Design Stage}

The product developed is a PBL-based physics learning tools consisting of a syllabus, lesson plan, student worksheet and PBL-based teaching material assisted by google classroom. The tools developed were adjusted to the indicators and learning objectives on the sub-topic momentum and impulse. Editing when designing is very necessary in order to get a good product. Furthermore, developing products that have been designed into products that can be applied to students. The following are some parts of the learning device design that will be developed.

\subsubsection{Syllabus Design}

The syllabus was developed according to the format stipulated in the Indonesian Minister of Education and Culture. The syllabus consisted of educational unit, class, semester, lesson, location and time. Meanwhile, the matrix consisted of core competencies, basic competencies, subject matter and learning activities. Figure 2 shows the display of the syllabus. 


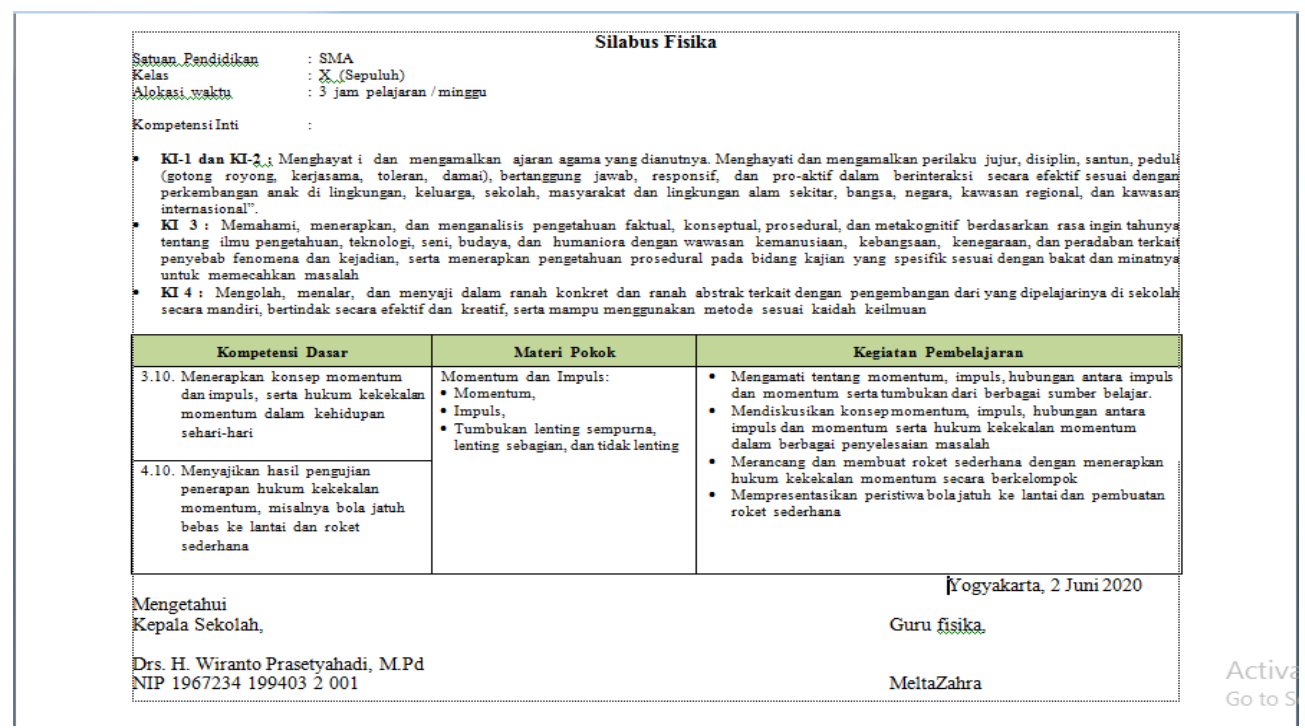

Figure 2 The display of problem-based learning syllabus

\subsubsection{Lesson Plan Design}

Lesson plan was prepared in accordance with the Permendikbud by following the 2013 curriculum. In addition, this lesson plan is also adapted to the steps of

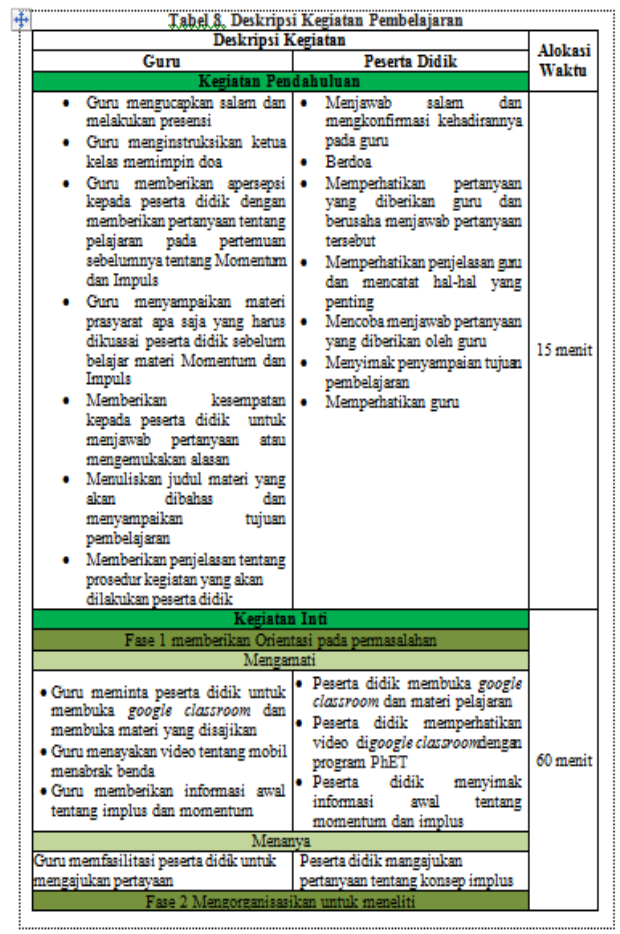

online problem-based learning assisted by Google's classroom. The syntax of PBL learning includes: providing orientation to problems, organizing students to research, conducting independent investigations, and developing and presenting results. Figure 3 shows the appearance of the PBL-based lesson plan.

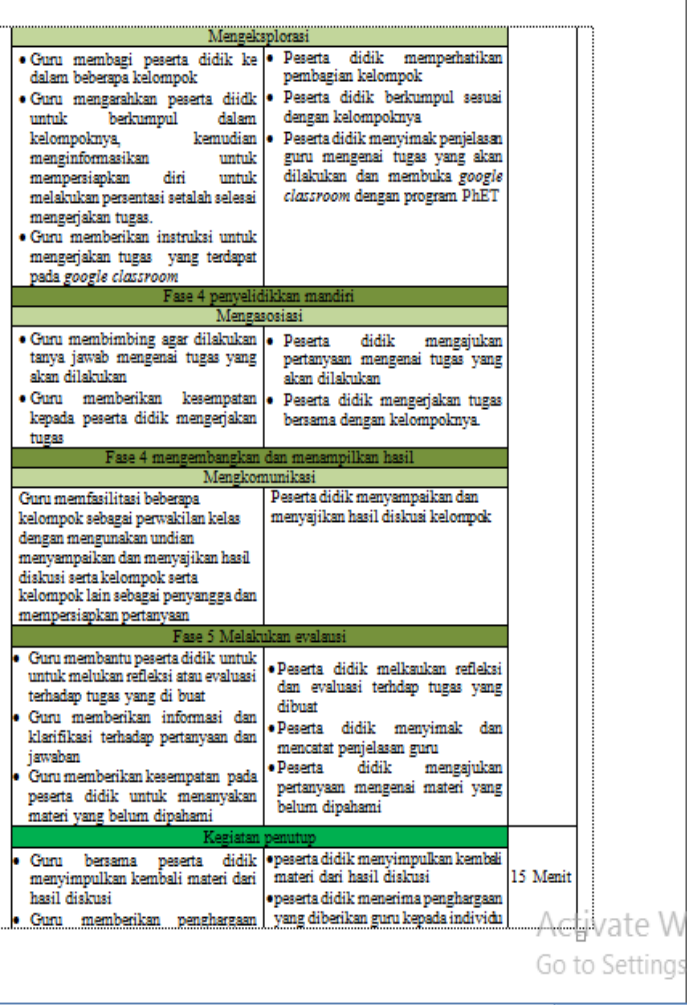

Figure 3 The display of the PBL-based lesson plan 


\subsubsection{Student Worksheet Design}

Student worksheet was designed in accordance with the 2013 curriculum which consisted of worksheets, answer sheets, and assessments. Not only that, this student worksheet was also prepared based on the PBL learning syntax using the google classroom platform. Student worksheet contain in-depth materials, problems, experimental analysis, and exercises. In this student worksheet, there is also a place for students to discuss with each other so that each student has basic knowledge. Figure 4 shows a part of PBL-based student worksheet
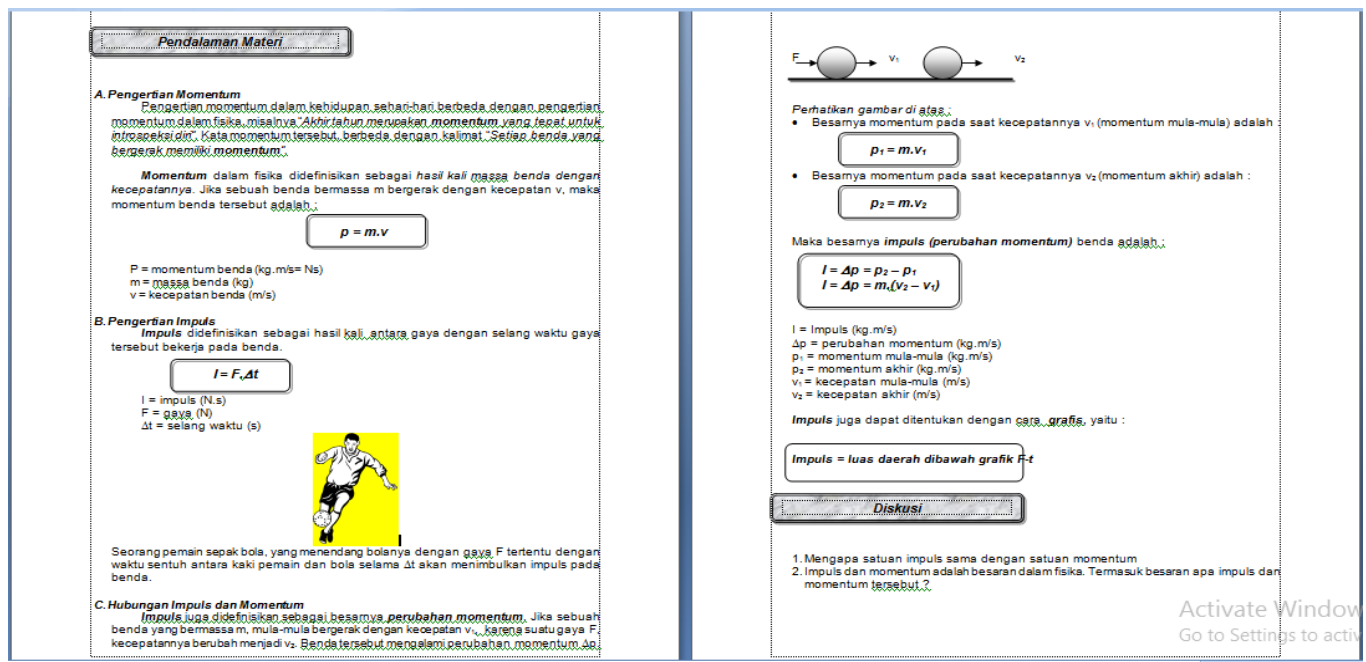

Figure 4 PBL-based student worksheet

\subsubsection{Teaching Material Design}

Teaching material was designed in accordance with the learning model and learning objectives. In this study, researchers used Problem Based Learning and followed PBL syntax.

\subsection{Develop Stage}

The product developed follows a valid design. PBL-based physics learning tools assisted by Google classroom were validated by experts and tested on students. Table 2 shows the results of validation by experts

Table 2. Learning tools validation result

\begin{tabular}{|c|l|c|c|}
\hline No & Component & $\begin{array}{c}\text { Average } \\
\text { Score }\end{array}$ & Criteria \\
\hline 1 & Syllabus & 3,67 & Strongly Valid \\
\hline 2 & Lesson Plan & 3,56 & Strongly Valid \\
\hline 3 & $\begin{array}{l}\text { Student } \\
\text { Worksheet }\end{array}$ & 3,18 & Strongly Valid \\
\hline 4 & $\begin{array}{l}\text { Teaching } \\
\text { Material }\end{array}$ & 3,49 & Strongly Valid \\
\hline
\end{tabular}

Based on table 2, all components of the learning tools developed obtained strongly valid criteria. The

syllabus got an average score of 3.67, lesson plans had an average score of 3.56, student worksheets had an average score of 3.18 , and teaching materials had a score of 3.49 (very valid). So that, the overall results are very valid and worthy of use in learning. There is no product revision in the field test so that learning tools can be distributed directly.

\subsection{Disseminate Stage}

This stage was carried out after the problem-based physics learning toolswere valid. The distribution of this product was conducted to teachers and students at MAN 1 Yogyakarta. Where student worksheets were used through Google classroom. And then, the results of students' responses to the developed products were obtained which are shown in table 3 .

Table 3. Result of student responses to physics learning tools

\begin{tabular}{|c|c|c|c|}
\hline No & Component & $\begin{array}{c}\text { Average } \\
\text { Score }\end{array}$ & Criteria \\
\hline 1 & $\begin{array}{c}\text { Content and } \\
\text { Purpose }\end{array}$ & 3,25 & Very Good \\
\hline 2 & Material Srlrction & 3,48 & Very Good \\
\hline 3 & Technical & 3,50 & Very Good \\
\hline 4 & Language & 3,35 & Very Good \\
\hline
\end{tabular}


Based on the table above, the technical aspect has the largest score, namely 3.50 very good criteria. The content and objective aspects have a very good score of 3.25 criteria and the material selection aspect has a very good score of 3.48 criteria. Dan has a very good score of 3.35 criteria. From the results of the overall response of students, it shows that the device developed is very good. Likewise, from the results of product validation, the development of learning tools using pbl is well applied in learning [19].

Problem based learning tools on impulse momentum material are good for class $\mathrm{X}$ MIA students. This physics learning tool has been developed in many physics lessons. This learning can be used by all classes to improve the abilities of students [13]. Previous research that supports this study google class can help students and teachers collaborate effectively [20]. In addition, Google Classroom can be accessed easily and for free.

\section{CONCLUSION}

Based on the results and discussion that has been described, it can be concluded that there was no development of physics learning tools that were tailored to the needs of students. So,we developed a learning tool based on PBL model which included a syllabus, lesson plan, student worksheet, and teaching material. The results of the product feasibility test indicated that this product is strongly valid to use. with this learning tool the interaction between teachers and students becomes more practical. but in teaching and learning activities require having a gadget and require a lot of money.

\section{REFERENCES}

[1] J. Afriana, A. Permanasari, A. Fitriani, Penerapan Project Based Learning Terintegrasi STEM untuk Meningkatkan Literasi Sains Siswa Ditinjau Dari Gender, Jurnal Inovasi Pendidikan IPA 2(2) (2016) 202-212. DOI: https://doi.org/10.21831/jipi.v2i2.8561

[2] T.D. Reeves, S.L. Honig, A Classroom Data Literacy Intervention for Pre-Service Teachers, Teaching and Teacher Education 50 (2015) 90101.

DOI:

https://doi.org/10.1016/j.tate.2015.05.007

[3] S. Sulistiyowati, A. Abdurrahman, T. Jalmo, The Effect of STEM-Based Worksheet On Students' Science Literacy, Tadris: Jurnal Keguruan dan Ilmu Tarbiyah 3(1) (2018) 89-96. DOI: https://doi.org/10.24042/tadris.v3i1.2141

[4] C. Drane, L. Vernon, S. O'Shea, The Impact of “
Learning at Home' on The Educational Outcomes of Vulnerable Children in Australia during The COVID-19 Pandemic, The National Centre for Student Equity in Higher Education, Apr. 2020. Accessed on: Jul. 27, 2020. [Online]. Available:

https://www.ncsehe.edu.au/publications/learnin g-at-home-educational-outcomes-vulnerablechildren-australia-covid-19/

[5] A.A. Hussin, Education 4.0 Made Simple: Ideas for Teaching, International Journal of Education \& Literacy Studies 6(3) (2018) 92-98. DOI: http://dx.doi.org/10.7575/aiac.ijels.v.6n.3p.92

[6] D. Rosana, D. Setyawarno, W. Setyaningsih, Development model of students' innert-depend strategies to face disruption era through best practice film of android based learning of pancasila character value, in: Journal of Physics: Conference Series, vol. 1233, IOP Publishing, Bristol, 2019. pp. 1-12. DOI: https://doi.org/10.1088/1742$\underline{6596 / 1233 / 1 / 012098}$

[7] A. Veloo, R. Nor, R. Khalid, Attitude towards Physics and Additional Mathematics Achievement towards Physics Achievement, International Education Studies 8(3) (2015) 3543. DOI: https://dx.doi.org/10.5539/ies.v8n3p35

[8] H. Georgiou, M.D. Sharma, Does Using Active Learning in Thermodynamics Lectures Improve Students' Conceptual Understanding and Learning Experiences?, European Journal of Physics 36(1) (2015) 1-13. DOI : https://doi.org/10.1088/0143-0807/36/1/015020

[9] H. Rosdianto, Implementasi Model Pembelajaran POE (Predict Observe Explain) untuk Meningkatkan Pemahaman Konsep Siswa pada Materi Hukum Newton, Jurnal Pendidikan Fisika 6(1) (2018) 55-58. DOI: https://doi.org/10.22611/jpf.v6i1.6899

[10] H.A. Agustin, S. Bektiarso, R.W. Bachtiar, Pengembangan Modul Komik Fisika pada Pokok Bahasan Hukum Kepler di SMA Kelas XI, Jurnal Pembelajaran Fisika 7(2) (2018) 168-174. DOI: https://doi.org/10.19184/jpf.v7i2.7924

[11] R. Phungsuk, C. Viriyavejakul, T. Ratanaolarn, Development of A Problem-Based Learning Model Via A Virtual Learning Environment, Kasetsart Journal of Social Science 38(3) (2017) 297-306.

DOI: https://doi.org/10.1016/j.kjss.2017.01.001

[12] E. Ince, An Overview of Problem Solving Studies in Physics Education, Journal of Education and Learning 7(4) (2018) 191-200. 
DOI: https://doi.org/10.5539/jel.v7n4p191

[13] Y. Yuberti, Online Group Discussion pada Mata Kuliah Teknologi Pembelajaran Fisika, Jurnal Ilmiah Pendidikan Fisika Al-Biruni 4(2) (2015) 145-153.

DOI: https://doi.org/10.24042/jpifalbiruni.v4i2.88

[14] A. Izenstark, K.L. Leahy, Google Classroom for Librarians: Features and Opportunities, Library Hi Tech News 32(9) (2015) 1-3. DOI: http://dx.doi.org/10.1108/LHTN-05-2015-0039

[15] M.N. Solikh, D. Sulisworo, G. Maruto, Pengaruh Model Pembelajaran Blended Learning Berbantuan Google Classroom terhadap Kemampuan Berpikir Kritis Ditinjau dari Self Esteem dan Kecerdasan Intelektual, Jurnal Materi dan Pembelajaran Fisika 2(8) (2018) 27 32.

DOI: https://doi.org/10.20961/jmpf.v8i2.28434

[16] A. Muslik, Google Classroom sebagai Alternatif Digitalisasi Pembelajaran Matematika di Era Revolusi Industri 4.0, Andragogi: Jurnal Diklat Teknis Pendidikan dan Keagamaan 7(2) (2019) 246-255.

DOI: https://doi.org/10.36052/andragogi.v7i2.98

[17] A. Wijaya, Analysis of factors affecting the use of google classroom to support lectures, in: Proceeding of The 5th ICIBA 2016, International Conference on Information Technology and Engineering Application, vol. 5, Universitas Bina Darma, Palembang, 2016, pp. 61-68.

[18] M.H. Hariadi, J. Jumadi, I. Wilujeng, H. Kuswanto, W. Wulandari, S. Sundari, Inquiry Training Learning Model Assisted by Google Classroom to Improve Creative Thinking Skills of Senior High School Students, Jurnal Pendidikan Indonesia 8(2) (2019) 198-207. DOI: http://dx.doi.org/10.23887/jpiundiksha.v8i2.17339

[19] H. Yarid, A. Ariswan, Pengembangan Perangkat Pembelajaran Fisika Problem Based Learning melalui Kegiatan Fieldtrip pada Materi Energi, Jurnal Inovasi Pendidikan IPA 2(1) (2016) 2434. DOI: https://doi.org/10.21831/jipi.v2i1.8374

[20] S. Iftakhar, Google classroom: What works and How?, Journal of Education and Social Science 3(1) (2016) 12-18. 